\title{
Elevated Urinary Pepsinogen: A Subclinical Marker of Ulcer Diathesis
}

\author{
M. Mujahlơ All, Pb.D., Mahboobunnisa, M.Sc, C. M. Habibullab, M.D., D.M. \\ Hyderabad, India
}

\begin{abstract}
Urinary pepsinogen levels were deterinind in 314 parienis with pepsic ulcer and in 100 healihy controls 10 see its possible role in parhogensis of peptic ulcer and to recognize elevaled levels of urinary pepsinogen as a subclinical marker of ulcer diashesis. All patients studied were endoscopically proved 10 have peptic ulcer. Significanily elevaled urinary pepsinogen levels were observed in patienis with duodenal ulcer, pyloric ulcer and sromal ulcer, but increased level of urinary pepsinogen in gastric ulcer was nat statislically significant when compared with conirols. Sixieen percent of patients with duodenal ulcer had pepsinogen levels similar lo the control group.
\end{abstract}

Key words: Pepric ulcer, urinary pepsinogen

DOI: http://dx.doi.org/10.5915/22-3-14307

A number of sludies have shown thal increased level of pensinogen both in serum as well as urine are associared wilh duodenal ulcer, ${ }^{-1}$ and a few studies have also found that an elevaled level is associared with an increascd risk for developing this disorder." ") Pepsinogen excrelion in the urine is supposed 10 reflect the peptic aclivily of the slomach, and it has been recommended as a quantitarive test for gastric secrelory funcrion." It also has been applied stinically 10 the study of peptic ulcer, pernicious anemia and gassric cancer.' No correlation has been found between urinary pepsinogen and gasuric acid secretion, while a positive correlation was observed between colal pepsinogen, pepsinogen-I and maximal acid output." A previous report from our center has shown a high degree of correlation becween serum pepsinggen and urinary pepsinogen. " Group-l

\footnotetext{
From the Deparimient of Gastroenterology

Osmonia Medical College

Osmanio General Haspual

Hyderabad, A.P., India.

Reprin! Requests: Dr. M. Mujatid Ali

Deporiment of Gostroenterology

Ormiania General Hospilal

Hyderahad, A.P., Indic.
}

pepsinogen is invariably present in the urine but group-II pepsinogen is rarely found in the normal urine. This is besause it exists in the circulation in a polymerized form and can not be fillered, or it is attached lo a servin prolein." "."

This siudy was conducied 10 detennine the urinary pepsinogen levels in different types of peptic ulccrs. such as duodenal ulcer (DU), gastric ulcer (GU). pyloric ulcer (PU) and stomal ulcer (SU), to find out the gastric secrelory function by the estimation of urinary pepsinogen, and to evaluale clevaled urinary pepsinogen as a subclinical marker of ulcer diarhesis.

\section{Materials and methods}

Two hundred and seventy-eight patients with DU (242 males and 36 females), ages belween 15 and 69 years (mean $43 \pm 16.41$ ), and 36 male parients with GU, PU, and SU (12 in each calogory) were siudied in the Department of Gastroenterology. Osmania General Hospital, Hyderabad, India. The selection of patients was based on endoscopic observations. One hundred age and sex matched healiny individuals without a history of peptic ulcer, dyspepsia or renal disease, served as conirols.

Twenty-four hour urine samples were collected from patienis and controls. An aliquot was used for the estimation of urinary pepsinogen. Urinary pep- 
Table 1. Mean urinary pepsinogen levels in controls and patients with peptic ulcer.

\begin{tabular}{lrc} 
Category & No. $\begin{array}{c}\text { Mcan urlagry pepsinogen } \\
\text { levels (mean } \pm \text { SD) in } \\
\text { Units/mi/24 hours }\end{array}$ \\
\cline { 1 - 1 } controls & 100 & $12 A 1.06 \pm 330.40$ \\
duodenal ulcer & 278 & $3440.84 \pm 1478.01^{*}$ \\
pyloric vicer & 12 & $3775.80 \pm 1176.72^{*}$ \\
stomal ulcer & 12 & $3897.81 \pm 1243.97^{*}$ \\
gastric ulces & 12 & $1419.29 \pm 562.98$
\end{tabular}

$=p<0.001$

sinogen was estimated within two days after the urine collecrion by the method of Mirsky et al' using hemoglobin as subsirate.

The sialistical significance of the difference in distribution of urinary pepsinogen levels in patients and controls was decermined by the Student's " $t$ " lest.

\section{Resulis}

The mean urinary pepsinogen levels in paijents ano controls are given in cable 1 . In controls the mean urinary pepsinogen was $1241.06 \pm 330.4$ units $/ \mathrm{ml} / 2 A$ hours (mean $\pm \mathrm{SD}$ ). A range of $600-1900$ was laken as nornal; any value beyono 1900 unils was regarded as hyper level, any value below 600 units was considered as hypo. In DU palients the urinary pepsinogen levels in male patients was 3564.81 \pm 1536.58 , and in Semale patients it was $2738.25=1346.46$ units $/ \mathrm{ml} / 24$ hours. Mean level of urinary pepsinogen both in male and female DU patienis was significantly increased as compared with the mean level of controls ( $\rho<0.001$ ). Of 242 male DU patients, $34(14 \%)$ had urinary pepsinogen within the norinal range, wheseas in 36 fermale palien1s, $10(28 \%)$ had normal level of urinary pepsinogen (figure 1). The mean urinary pepsinogen in GU parients was 1419.29 \pm 502.98, in PU $3775.80 \pm$ 1176.72 and in SU it was 3897.81 51243.97 unils/ml/24 hours. The increased mean level of urinary pepsinogen in PU and SU was slatistically significan when compared with the mean level of controls, but the increased mean level of pepsinogen in GU was not statistically significane.

\section{Discusaion}

Urinary hyper-pepsinogenuria was recorded in $84 \%$ of DU patients in this sıudy, whereas only $16 \%$ of the DU patients had pepsinogen levels in the nosmal range. In a previous sludy,' we classified DU patiencs into two groups anthe basis of tolal serum oepsinogen level: 1) primary DU, where hyperpepsinogenemia was associated, and 2) secondary DU, in which hyperpepsinogenenia was not associaled

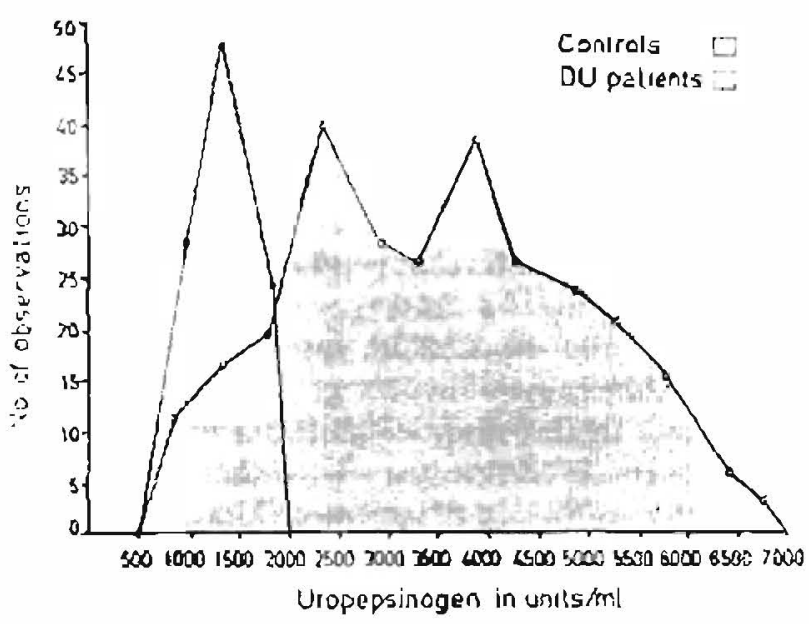

Figure. Frequency distribution of urinary pepsinogen levels in duodenal ulcer palients and in conirol populacions. Overlap represen $1516 \% 0$ of ulcer patents whose pepsinoger concentration fell within the concrol range.

with the disease. In that study $83 \%$ of patients had primary DU and 17\% had secondary DU. Similar results were observed in this scudy when we used urinary pepsinogen as a marker. This scudy confirms that either serum or urine can be utilized to estimate the pepsinogen. Our previous report": regarding positive correlation between total serum pepsinogen and urinary pepsinogen is also confirmed by this study.

The pepsinogen present in the urine is group-l pepsinogen in serum, which plays an important role in the pathogenesis of pcptic vicer. The derection of group-I pepsinogen is difficule since it can only be detected by a radioimmunoassay method. In urine, the group-l pepsinogen can be esrimated by simple colorimesic method.

The peplic secrelory cell mass is in fluenced by sex and ABO blood gene." the pepsinogen levels probably reflect the size of the gastric cell mass. This is generally smaller in females, so pepsinogen level is alwzys lower in remales. Our results are in agreement with the previous report" by showing lower values of pepsinogen in females.

In all the parienis where hyperpepsinogenemia was recorded here will be increased acid secrecion. Based on the prevailing concept that the concentration of pepsinogen in serum as well as urine reflece the capacily of the gastric mucosa lo secrete hydrochloric acid. I $\mathrm{L}$ is generally accepted that an elevated serum pepsinogen level indicates gastric acid hypersecretion, and that a low level predicts hypochlorohydria or achlorohydria, ${ }^{10}, 1$ The measurement of urinary pepsinogen can be recommended as a screening lest for the derection of achlorohydria, hypochlorohydria and hyperchlorohydria, because uropepsinogen excretion closely parallels gastric acid." 
Signilicantly elevated levels of urinary pepsinogen were recorded not only in DU but also in PU and SU parients; in GU it was in tho nornal range except in three patients where the levels were slightly elevared. There might be increased chief cell and parietal cell mass in PU and SU as has been recorded in DU patients. ${ }^{9}$ making the level of pepsinogen higher in boih PU and DU ulcers as in Du. Sometimes pepsinogen levels are also elevatcd in palients with GU;'s': however, the cause of hyperpepsinogenemia in GU is not clear. In this disorder gastric acid output and pepsinogen levels are usually within the normal range; 130 association of increased chief cell mass and parictal cell mass has been noted with GU. It is generally accepted that decreased mucosal resistance secondary 10 gastritis is a major factor in the parhogenesis of GU." ${ }^{1,18}$

It has been suggested that pepsinogen secretion has an endocrine as well as exocrine component. ${ }^{23}$ The high levels of serum and urinary pepsinogen results from an incteased chief cell mass ${ }^{10}$ which is genecically decermined." so that the endocrine component tends to keep the levels of pepsinogen elevated in these indivuduals. In the absence of overt clisease this elevated level serves as a genetic as well as a subclinical marker for an ulcer diachesis. le may be assumed that in persons with the ulcer irait that ressing exocrine component of pepsinogen merely gives rise to hypersecretion. This does not necessarily result in the formation of ulcer because various "cyloprotective" mechanisms become active." The finding of Kollberg el al" that oral PGE 2 acceleraies healing of the DU purely by stimulating the cytoprotective mechanism without inhibiting acid secretion lends further support to our conrention. Hypersecretion remains precariously balanced against cytoprotection. Cerlain aggravating factors may disrupt this delicate balance by stimulating the exocrine limb causing further hypersecretion, resulting in ulceration of the mucosa. Similarly cerlain other factors may mediale loss of cytoprotection, (ilting the balance again in (avor of uiceration. Some aggravating factors may do both. Acule DU does $n 01$ result in a furcher rise in serum and urinary pepsinogen, indicating that the endocrine component is not under stimulation. ${ }^{26}$ Factors like ACTH may additionally stimulate the endocrine component of pepsinogen secretion so that there is a furlher rise in the elevated serum and urinary pepsinogen."

In secondary DU, which is supposed to be either of neuroendocrinological origin or due to a viral infection," the levels of serum and urinary pepsinogen are not elevated. There is no hypersecretion making the subject susceptible to DU. However, the same aggravating factors which selectively stimulate the exocrine limb of pepsinogen or cause a disruption of the cytoprotective mechanism may, under extreme conditions, give rise 10 peptic ulceration. There being no increased chief cell inass, nor a stimulaced endocrine limb, the serum as well as the urinary pepsinogen levels remain wichin normal limits. Menguy et al ${ }^{29}$ have proposed that stress uicers (which may be included in secondary DU) are the result of mucosal energy deficils severe enough to cause cellular necrosis. Because this mechanism is unrelated 10 hypersecretion. such ulcers obviously do not have associated hyperpepsinogenemia and also do not menifest increased excretion of uropepsinogen.

In conclusion, a high uropepsinogen excretion is seen in patients suffering from peptic ulcer, particularly duodenal ulcer, pyloric ulcer and siomal ulcer. High levels of urinary pepsinogen may also indicale the hyper gastric secrelory function, and an elevated urinary pepsinogen level may serve as a subclinical marker of ulcer diathesis.

\section{References}

1. Mirsky IA, Futherman P, Kaplan S: Blood plasma pepsinogen.1I The aciivity of the plasma from "normal" subjects, paricnts wirl duodenal ulcer and patients with pernicious anemia. J Lab Clin Med 19.52; 40: 188-99.

2. Habibullah CM, Mujahid AM, Ishaq $M$, et al: Sudy of duodenal ulcer disease in 100 families using tolal serum pepsinogen as a genetic marker. Gut 1984;25:1380-1383.

3. Rotter I, James QS, Samloff IM, et al: Duodenal ulcer disease with elevaled serum pepsinogen-I. An inherited autosomal disorder. New Engl J Med 1979;300:63-65.

4. Weiner H, Thaler M, Resiser MF, Mirsky IA; Etiology of duodenal ulcer. 1. Relasion of specific psychological characteristics 10 rate of gastric secretion (serum pepsinogen). Psychosom Med 1957;19:1-10.

5. Niederman JC, Spiro HM. Sheldon WH: Blood pepsin as a marker of susceptibility to duodenal ver disease Arch Environ Healih 1964:8:540-546.

6. Hirschowilz Bli Urinary Excrecionof pepsinogen in astroduodenal ulceration. Lancer 1953:1:66-69.

7. Bolt RJ, Pollard HM, and Carballo A: Determination of gastric secretory function by measurement of substances excreled by kidney. I. Uropepsin excrerion in health and disease. I Lab Clin Med 1954; 43: 335-339.

8. Gray SJ, Ramsey CG, Reifenstein RM: Clinical use of the urjary uropepsin determination in medicine and surgery. $N$ Engl J Med 1954: 251: 835-843

9. Mujahid AM, Habibullah CM, Ishaq M, Saleem $Y$ : Relation between gastric acid secrelion and lolal serum pepsinogen levels in duodenal ulcer. Trop Gastroenterol 1986;7:62-64.

10. Samlot IM, Donald M, Passaro E: A study of 
the relationship belween serum group-l pepsinogen levels and gastric acid secretion. Gastroenterology 1975;69:1196-1200.

11. Plebani M. Dimario F, Vianello F. el al: Pep. sinogen gToup-l radioinmunoassay and cotal serum pepsinogen colorimetric defermination: A comparalive scudy in normal subjects and in pepIic ulcer patients. Clin Biochem 1983;16:20-22.

12. Habibullah CM, Mujahid AM, Ishaq M. Quadri GSA, Saleem Y: Relalionship of urinary pepsinogen with serum pepsinogen in duodeaal ulcer. Trop Gastroenter ol 1985;6:26-29.

13. Seijiffers MJ, Segal HL, Miller LI: Separation of pepsinogen 11 and pepsinogen III from human urine, Am J physiol 1964;206: I 106-1110.

14. Samloff IM, Townes PL: Electrophoreric heterogeneity and relalionships of pepsinogens in human urige, serum and gastric mucosa. Gastrocnicrology 1970;58:462-469.

15. Hirschowilz B1: Pepsinogen in the blood. J Lab Clin Med 1955;46:568-579.

16. Hoar CS, Browning JR: Plasma pepsinogen in peptic ulcer disease and other gastric disorders A clinical and laboratory investigation. $N$ Engl J Med 1956;255:153-58.

17. Ippolici A. Walsh J: Newer concepts in the palhogenesis of oepric ulcer disease. Surg Clin North Am 1976;56:1479.1490.

18. Rhodes J: Eriology of gastric ulcer. Gastroentcrology 1972;63:171.82.

19. Hanley WB: Hereditary aspects of duodenal ulceralion. Br Med J 1964; 1:936-940.

20. Chin AB: Sudies on blood serum proteolyric ел- zyme with particular reference 10 gaseric secrecosy function. Gastroenterology 1953;25:14-23.

21. Fischermann K, Sirande KS, Peterson PH: Pepsinogen determinarion as a possible means for evaluation of gastric acid secretion Gasiroenterology 1975;69:196-200.

22. Cubberly DA, Dagradj AE, Carnelto G, Scemplix S1: Uropepsinogen excretion in gastroduodenal diseases. Gastroenterology 1955;28:80-87.

23. Samloff IM: Pepsinogen, pepsins and pcpsin inhibilors. Progress in Gastroenlerology $1971 ; 60: 586-604$.

24. Guth PH: Pathogenesis of gastric nucosal injury. Ann Rev Med 1982:33:183-196.

2S. Kollberg B. Johanson C, Stezak P: Duodenal ulcer healing with prostaglandin $E_{2}$. Gasiroenterology 1981:80:1195-1200.

26. Spiro HM, Ryan AE. Jones CM: The urility of the blood pepsin assay in clinical medicine. $N$ Eng) J Med 1955:253:261-266.

27. Spiro HM, Reifenstein RW, Gray SJ: Effecl of adrenocorticotropic hormone upon uropepsin cxcretion. J Lab Clin Med 1950:35:899-910.

28. Habibullah CM, Mujahid AM, Nayana J, Abideen $\mathrm{KZ}$ : Cyromegalovirus and Herpes simplex vírus in duodenal ulcers. Med Sci Res 1988:16:923.

29. Menguy R, Desbaillecs L, Masters YF: Mechanism of siress ulcer. Influence of hypovolemic shock on cnergy metabolism in the gastric mucosa. Gastroenterology 1974:66:46-55.

Editor correction November 24, 2014.

Reference 21 should be:

Fischermann K, Strande CS, Petersen PH. Pepsinogen determinations as a possible means for evaluation of gastric acid secretion. Am J Gastroenterol. 1971 Nov;56(5):447-52.

Reference 22 should be:

Cubberley DA, Dagradi AE, Carne HO, Stempien SJ. Uropepsin excretion in gastroduodenal disease; a correlative clinical study. Gastroenterology. 1955;28:80-87. 